\title{
Dominik Antonowicz
}

\section{Rady powiernicze w szkolnictwie wyższym}

\begin{abstract}
STRESZCZENIE: Przedmiotem niniejszego artykułu są rady powiernicze w europejskim szkolnictwie wyższym. Analiza obejmuje proces kształtowania się idei rad w różnych tradycjach szkolnictwa wyższego, zwracając szczególną uwagę na rolę, jaką im przypisywano w budowaniu relacji między uczelniami a otoczeniem zewnętrznym. Praca nie ma wyłącznie charakteru historycznego, choć jej duża część poświęcona jest analizie dyskursu dotyczącego procesu powoływania i organizacji rad powierniczych w europejskich uczelniach. Jej centralnym elementem jest analiza modeli rad powierniczych w uczelniach pod względem posiadanej władzy oraz odpowiedzialności, sposobu mianowania/odwoływania ich członków, rozliczania rady powierniczej, a nade wszystko ich składu, w tym zwłaszcza udziału reprezentantów zewnętrznych interesariuszy. W ostatniej części - nawiązując do doświadczeń innych krajów - poruszona zostaje kwestia potencjalnych wyzwań, jakie wynikają dla polskiego szkolnictwa wyższego w związku z publicznie dyskutowaną możliwością powołania rad powierniczych w polskich uczelniach.
\end{abstract}

SŁOWA KLUCZOWE: szkolnictwo wyższe, ustrój uniwersytetu, reformy, rady powiernicze, społeczeństwo interesariuszy

Niemal przez cały XX wieku uniwersytety europejskie były zarządzane przez wspólnoty akademickie, zwłaszcza środowisko profesorów, które tradycyjnie odgrywało w nich dominującą rolę. Taki stan rzeczy nie tylko odzwierciedlał głęboko zakorzenioną i zinstytucjonalizowaną akademicką tradycję, ale również silne przekonanie badaczy, że jest to najlepszy sposób kierowania instytucjami akademickimi (Moodie i Eustace 1974). Ostatnie dekady XX wieku upłynęły jednak pod znakiem rosnącej krytyki demokratycznego ustroju akademickiego w wielu krajach Europy Zachodniej głównie w wyniku ich nieefektywności (powolność i nieporęczność), jak 
również nieskuteczności (ukierunkowanie do wewnątrz i zaniedbujące zewnętrzne oczekiwania) (Boer, Denters i Goedegebuure 1998: 153). Otworzyło to drogę do poszukiwania nowych rozwiązań ustrojowych odpowiadających na istniejące deficyty, ale i zmieniających trwale zakorzenione w tradycji akademickiej struktury organizacyjne.

Przedmiotem artykułu są uniwersyteckie rady powiernicze (ang. supervisory boards), czyli organy, które w europejskim szkolnictwie wyższym pojawiły się pod koniec XX wieku i stopniowo, ale konsekwentnie wprowadzane są jako organy ustroju instytucji (Boer i in. 1998). ${ }^{1}$ Rady powiernicze stanowią polityczny symbol zmian zachodzących w myśleniu o szkolnictwie wyższym, a jednocześnie same są ważnym organem nowego modelu ustroju uczelni. Ich wprowadzenie oparte zostało na normatywnym przeświadczeniu, że „uniwersytety muszą być bardziej otwarte i lepiej wpisywać się w społeczne i gospodarcze środowisko, a dlatego potrzebują większej autonomii, aby lepiej odpowiadać na zmiany otoczenia" (Amaral i Magalhães 2001; Magalhães, Veiga, Amaral, Sousa i Ribeiro 2013) i lepiej funkcjonować (Aghion, Dewatripont, Hoxby, Mas-Colell i Sapir 2010; Ritzen 2011; Magalhães, Veiga i Amaral 2016: 1). Ich wprowadzeniu towarzyszyły ogromne polityczne i środowiskowe kontrowersje, liczne wątpliwości, a niekiedy wręcz protesty (np. Pechar 2005; Aarrevaara 2012; Välimaa 2007; Luzzatto i Moscati 2005), które mimo swej intensywności i emocjonalnego charakteru zasadniczo nie były wstanie powstrzymać fali zmian. Reformy uniwersytetów przede wszystkim oznaczały fundamentalną przemianę relacji pomiędzy instytucją państwa a uczelniami (Boer, Maasen i Weert 1999; Henkel i Askling 2006; Kehm i Lanzemdorf 2006; Jabłecka 2002). W ich wyniku uczelnie zyskały szerszą autonomię organizacyjną oraz finansową (de Boer, Jongbloed, Enders i File 2010; Enders, de Boer, i Weyer 2013), ale zostały też postawione przed koniecznością większej społecznej rozliczalności z realizacji przyjętych celów, choć wcześniej rozliczalność miała charakter środowiskowy (ang. professional accountability) (Huisman i Currie 2004). Obecnie rady powiernicze funkcjonują już w wielu europejskich krajach, choćby Anglii, Austrii, Holandii, Włoszech, Portugalii, Finlandii, Niemczech czy Rosji, a ich główną cechą charakterystyczną jest obecność w nich osób spoza wspólnoty akademickiej. Wyróżnia to je spośród pozostałych organów uczelni, ale też stanowi źródło ich największej środowiskowej krytyki.

Chociaż rady powiernicze w europejskim szkolnictwie wyższym pojawiły się stosunkowo niedawno, to zdołały wywołać spore zainteresowanie badaczy szkolnictwa wyższego. Przede wszystkim w ramach badań ukierunkowanych na - szeroko rozumiane - przemiany ustrojowe uniwersytetów europejskich (Amaral, Meek, i Larsen

${ }^{1}$ W artykule kategoria „rad powierniczych” oraz „rad uczelni” będzie używana zamiennie, bowiem tak też zostało przyjęte w dyskursie publicznym. 
2003; Veiga, Magalhães i Amaral 2015), których integralna częścią było właśnie powołanie rad uczelni. Warto jednak zaznaczyć, że same rady - jako odrębny przedmiot badań - stały się również przedmiotem analiz (Kretek, Dragšić i Kehm 2013; H. de Boer, Huisman i Meister-Scheytt 2010; De Boer i File 2011). W sumie jednak literatura poświęcona radom uczelni nie jest szczególnie bogata, w przeciwieństwie do literatury na temat funkcjonowania rad nadzorczych oraz powierniczych w sektorze przedsiębiorstw (np. Huse 2007), jej zastosowanie do studiów nad uczelniami jest jednak mocno ograniczone.

Dotychczasowe badania nad radami powierniczymi w szkolnictwie wyższym są na wstępnym etapie i wśród licznych studiów nad przemianami struktury uczelni analizy poświęcone radom powierniczym stanowią stosunkowo niewielką część. Bez wątpienia jednak zainteresowanie tym zagadnieniem wśród badaczy systematycznie rośnie. Ze względu na różne tradycje akademickie, odmienne doświadczenia historyczne, a przede wszystkim różnice w systemach szkolnictwa wyższego każda z reform jest swoistym fenomenem, który wymaga odrębnej analiz towarzyszących im społeczno-politycznych uwarunkowań. Nie powinno więc dziwić, że to one dominują w literaturze przedmiotu, obejmując takie kraje jak Holandia (de Boer i File 2011), Austria (Meister-Scheytt 2007), Portugalia (Veiga i in. 2015), Włochy (Donina, Meoli i Paleari 2015) czy Rosja (Gryaznova 2017). W ostatnich latach pojawily się również badania, a w ślad za nimi publikacje dotyczące kompozycji rad powierniczych (Bradford, Guzmán, Restrepo i Trujillo 2017), a także próby pierwszych ewaluacji ich funkcjonowania w strukturach uczelni (Magalhães i in. 2016). Niestety trudno jest wskazać polskojęzyczne publikacje poświęcone radom powierniczym, a jeśli się takie pojawiają, to ma to miejsce, albo w kompleksowych dokumentach o charakterze ekspertyz (Kwiek i in. 2016; Woźnicki in in. 2015), albo w przeglądowych tekstach o przemianach w europejskim szkolnictwie wyższym (np. Wójcicka, 2002). Najczęściej temat rad powierniczych pojawia się jednak w krytycznych analizach neoliberalnej fali reform instytucji akademickich (Szwabowski 2014). Można zatem powiedzieć, że mimo ogromnych kontrowersji, jakie wywołują rady uczelni w polskim środowisku akademickim, dyskusja nad nimi ma charakter głównie publicystyczny i przepełniona jest politycznymi emocjami. Z tego powodu niniejszy artykuł stawia sobie trzy zasadnicze cele: (a) przedstawienie szerszego kontekstu wprowadzenia rad powierniczych do uczelni europejskich, w tym zwłaszcza w kontekście kształtowania się społeczeństwa interesariuszy; (b) lepsze zrozumienie roli, jaką odgrywają rady powiernicze poprzez identyfikacje pełnionych przez nie funkcji, zakresu ich kompetencji oraz analizę modeli funkcjonowania rad powierniczych, a także mechanizmów ich rozliczalności; (c) wskazanie na główne wyzwania stojące przed polskimi uczelniami $\mathrm{z}$ uwagi na wprowadzenie rad powierniczych. 


\section{Od państwa narodowego do społeczeństwa interesariuszy}

Idea rad powierniczych w szkolnictwie wyższym według Guya Neave’a (2003) jest silnie związana z kształtowaniem się społeczeństwa interesariuszy (ang. stakeholder society). Zresztą sama kategoria „interesariuszy” nie jest zupełnie nowa w obszarze szkolnictwa wyższego, gdyż już najstarsze uniwersytety europejskie musiały się mierzyć z oczekiwaniami rozmaitych interesariuszy niezależnie od tego, czy byli to studenci, lokalni władcy, czy też kościelni mocodawcy. Uzależnione finansowo od hojności i politycznej protekcji musiały tak manewrować pomiędzy różnymi ośrodkami władzy, aby nie tracąc ich przychylności (i finansowania), zachować możliwie szeroką autonomię. Nie było to łatwe wyzwanie, bowiem oczekiwanie poszczególnych grup różniły się od siebie, a często wręcz wzajemnie się wykluczały. Co zrozumiałe, im większa była rola uniwersytetów, tym większe wobec nich formułowano oczekiwania i trudniej było im sprostać. Przełom pojawił się dopiero wraz z kształtowaniem się nowoczesnego państwa narodowego w Europie, gdy relacje pomiędzy szkolnictwem wyższym a państwem uległy fundamentalnej redefinicji. Kluczowymi elementami tej zmiany była nacjonalizacja szkolnictwa wyższego oraz etatyzacja stanu akademickiego, czyli jego włączenie do struktur administracji państwowej (Kwiek 2000; Antonowicz 2005). Uczelnie zyskały możnego protektora, który jednocześnie posiadał monopol na definiowanie oczekiwań wobec uczelni. Była to istotna zmiana, którą Neave (2003: 25) określił mianem przeniesienia własności uczelni ze stanu profesorów na instytucje państwa. Było to typowe dla krajów Europy kontynentalnej, gdyż w Stanach Zjednoczonych ten transfer własności nastąpił na rzecz społecznych powierników (ang. trustees). W Europie Zachodniej „przeniesienie własności nie było jedynym znaczącym krokiem w europejskim szkolnictwie wyższym. Upaństwowieniu towarzyszyło przeniesienie wielu innych funkcji i warunków. Głównym celem jego transferu było stworzenie nierozerwalnego związku między odpowiedzialnością stanu akademickiego a interesem narodowym" (Neave 2003: 25). Znacząco zacieśniło to relacje między państwem a uczelniami (w zasadzie oligarchią akademicką), które można uznać za swoisty pakt, w ramach którego instytucja państwa gwarantuje uczelniom autonomię, ale zarazem określa prawne ramy ich funkcjonowania oraz rości sobie monopol do artykułowania wobec nich własnych oczekiwań związanych z kształceniem elit i budowaniem nowoczesnego państwa narodowego.

Uniwersytet humboldtowski był instytucją autonomiczną oraz samorządną, co miało istotny wpływ na jego ustrój nadający uczelniom korporacyjny charakter (w znaczeniu korporacji zawodowej) i zapewniający jej wewnętrzną stabilność oraz równowagę interesów pomiędzy różnymi wydziałami. Władze uczelni odpowiedzialne były wyłącznie przed społecznością akademicką, a precyzyjnie rzecz ujmując przed społecznością profesorów, która ją de facto tworzyła. W sposób zaplanowany 
uniwersytet humboldtowski nie miał budować relacji ze światem zewnętrznym, bowiem to instytucja państwa miała być jego jedynym reprezentantem. To państwo bowiem definiowało, co leży w interesie publicznym i w jaki sposób należy go realizować. Ponadto miało ono chronić uczelnie przed próbami współpracy z podmiotami zewnętrznymi (innymi niż państwo), bowiem mogłyby to potencjalnie zakłócić ich funkcjonowania. W sensie bardziej ogólnym uczelnie funkcjonowały w ramach narzuconego przez państwo regulowanego porządku, w którym za pomocą władzy centralnej ustanawiano relacje z zewnętrznymi podmiotami, ale również stosunki pomiędzy poszczególnymi interesariuszami wewnętrznymi (społecznością uczonych, pracownikami administracji oraz studentami) były szczegółowo określone ustawowo. Flagową cechą humboldtowskiego modelu szkolnictwa wyższego stała się zatem obecność regulowanego porządku, narzuconego zresztą odgórnie przez władzę publiczną. Władza w ten sposób pełniła rolę strażnika interesu ogólnego, pośrednicząc niejako w kontaktach pomiędzy szkołami wyższymi a społeczeństwem, tworząc swoistą „przestrzeń ochronną wokół uniwersytetów, służących państwu narodowemu" (Neave 2003: 29).

Model ten przetrwal do końca lat 6o. XX wieku, gdy umasowienie szkolnictwa wyższego podważyło paradygmat uniwersytetu jako korporacji profesorów, a trwałość regulowanego porządku, w ramach którego podmiotowość studentów była minimalna, została mocno zachwiana gwałtownie rosnącą liczbą i siłą studentów. Ich obecność spowodowała, że podważona została rola uczelni jako instytucji dokonującej selekcji i przygotowującej najbardziej zdolną młodzież do pracy w sektorze publicznym, zapewniając w ten sposób stabilność porządku społecznego i sprawność funkcjonowania państwa. Natomiast wraz z rosnącą liczbą absolwentów wchodzącą na rynek pracy rosło zainteresowanie efektami kształcenia ich potencjalnych pracodawców, w tym zwłaszcza z sektora prywatnego, którzy dotychczas nie mieli znaczących powodów, żeby artykułować własne potrzeby w tym zakresie. Jednak umasowienie miało zdecydowanie bardziej istotne konsekwencje dla ustroju i sytuacji wewnątrz uczelni, gdyż pojawienie się dużej liczby studentów oraz młodszych pracowników naukowych doprowadziło do zakwestionowania koncepcji „uczelni profesorów" przez studentów, jak i młodszych pracowników, którym ze względu na niski status w systemie przypisywano role pomocniczą (Klimke i Scharloth 2008). Był to pierwszy, ale jednocześnie niezwykle ważny krok w stronę rozbicia stanu akademickiego i wyodrębnienia się grupy wewnętrznych interesariuszy: studentów, młodszych pracowników oraz pracowników administracji, których potrzeby oraz interesy znacząco się różniły. Zwłaszcza gwałtowny wzrost liczby młodszej kadry akademickiej i jej relatywnie niewielkie prawa w systemie szkolnictwa wyższego doprowadziły do poważnych napięć na linii profesura-młodsi pracownicy naukowi. Konsekwencją studenckiej rewolucji dla ustroju uniwersytetów europejskich było upodmiotowienie 
studentów, młodszej kadry naukowej, a także pozostałych zatrudnionych w uczelni jako odrębnych interesariuszy. W miejsce humboldtowskiego „uniwersytetu profesorów" pojawił się demokratyczny ustrój - wprowadzany w latach 70. XX wieku w uniwersytetach w krajach Europy Zachodniej - w którym wszyscy wewnętrzni interesariusze mieli zagwarantowany udział we współzarządzaniu uczelnią poprzez odpowiednią kompozycję organów kolegialnych. W jej konsekwencji nastąpiła rekonfiguracja ośrodka władzy i wprowadzenie demokracji uczestniczącej (ang. participant democracy) do szkół wyższych dopuszczające młodszą kadrę oraz studentów do procesu współzarządzania i współodpowiedzialności za uczelnię. Wprawdzie szkoły wyższe nadal pozostawały pod kontrolą profesury, ale pozycja i wpływ tej grupy na bieżące funkcjonowanie uczelni zostały znacząco ograniczone na rzecz przedstawicieli pozostałych interesariuszy wewnętrznych. Co ciekawe, proces dyferencjacji wewnętrznych interesariuszy postępuje dalej zarówno na poziomie uczelni, jak również na poziomie systemowym. Ilustracją tego procesu jest emancypacja doktorantów ich potrzeby (interesy) zaczęły na tyle istotnie się różnić od szeroko rozumianych studentów, że zaczęli domagać się osobnej reprezentacji, którą w wielu krajach utworzono. W Polsce taką rolę pełni Krajowa Reprezentacja Doktorantów (KRD) na poziomie systemowym oraz samorząd doktorantów na poziomie uczelnianym, obie pojawiły się dopiero w XXI wieku.

Ustrój uczelni jest konstrukcją dynamiczną i ewoluuje pod wpływem dynamiki procesów zachodzących zasadniczo poza szkolnictwem wyższym, ale mających daleko idące konsekwencje dla jego funkcjonowania na poziomie systemowym, ale również, a może przede wszystkim dla ustroju uczelni. Generalnie, jak zauważa Neave (2003), jest to proces tworzenia się społeczeństwa interesariuszy w szkolnictwie wyższym. Pierwszy etap transformacji w kierunku społeczeństwa interesariuszy wiódł poprzez wewnętrzne różnicowanie wspólnoty akademickiej i nadanie podmiotowości oraz formalnej władzy przede wszystkim licznej grupie studentów oraz młodszych pracowników naukowych. Narzucony przez państwo „regulowany porządek”, który we wspólnocie akademickiej dostrzegał wyłącznie profesorów i im też przypisywał prawo reprezentowania całej społeczności akademickiej, niemal całkowicie legł w gruzach. W jego miejsce pojawił się demokratyczny model ustroju instytucji akademickiej, nadając podmiotowość i dopuszczając do współrządzenia uczelnią przedstawicieli wszystkich wewnętrznych interesariuszy oraz tworząc z niej formę demokracji uczestniczącej, w której jednak wiodącą rolę zachowali profesorowie.

Konsekwencją tych zmian, określanych przez Neave’a (2003) jako tworzenie się społeczeństwa interesariuszy, jest stopniowe podważanie państwa jako emanacji interesu społecznego oraz jako wyłącznego pośrednika w relacjach między uczelniami oraz otoczeniem zewnętrznym. Wiąże się to z jednej strony z wycofywaniem się państwa z obszarów szkolnictwa wyższego na rzecz podmiotów rynkowych, quasi- 
-autonomicznych agencji finansowanych ze środków publicznych oraz organizacji pozarządowych (Bleiklie 1998), a z drugiej z rozmywaniem się koncepcji nowoczesnego państwa narodowego, którego siła jest osłabiana przez ponadnarodowe polityczne struktury, a także władze regionalne oraz lokalne. Zwłaszcza, że na poziomie polityki publicznej sterowanie szkolnictwem wyższym stało się bardziej złożonym procesem ze względu na liczbę zaangażowanych aktorów (multi-level multi-actor governance) (Kersbergen i Waarden 2004; De Boer, Enders i Leisyte 2007), którzy oddziałują (poniekąd niezależnie) na jej kształt, proces implementacji, a także ewaluację. Konsekwencją tego jest konieczność redefinicji relacji uczelni ze światem zewnętrznym, której nie sposób sprowadzić wyłącznie do relacji z administracją centralną, czyli resortem realnie odpowiedzialnym za naukę oraz szkolnictwo wyższe. Przede wszystkim aktywność państwa przyjmuje zupełnie nową formułę, odchodząc od bezpośredniego zaangażowania w formie biurokratycznych interwencji (ang. intervetionary state) w kierunku bardziej pośrednich, ukierunkowujących czy nawet wspierających działań (ang. facilitatory state). Jednocześnie rząd, czy precyzyjniej rzecz ujmując administracja rządowa, pozostaje nadal ważnym, ale już nie jedynym partnerem dla szkół wyższych, bowiem interes publiczny ulega istotnemu rozproszeniu i nie jest już wyłącznie definiowany przez pryzmat interesów władzy centralnej. Co więcej, oczekiwania władzy mogą się znacząco różnić od oczekiwań pozostałych interesariuszy, zwłaszcza jeśli sukces tych ostatnich coraz mocniej zależy od wiedzy oraz innowacji. Taka zmiana w polityce publicznej oznaczała konieczność uwolnienia instytucji szkolnictwa wyższego spod ścisłej kontroli państwa egzekwowanej poprzez detaliczne regulacje oraz umożliwienie im możliwie najszerszej swobody do określania własnej struktury. Jak podkreśla Harry de Boer (2017: 3), „[t]aka zmiana ustroju często pociąga za sobą uwolnienie instytucji szkolnictwa wyższego z detalicznej kontroli legislacyjnej poprzez umożliwienie im kształtowania własnej struktury w ramach poszerzającej się przestrzeni własnej autonomii. Wzmocnienie instytucjonalnej autonomii jest jednym z nadrzędnych trendów w europejskim szkolnictwie wyższym". Podstawą takiego myślenia jest wiara, że zwiększenie autonomii uczelni i odstąpienie od mikrozarząadzania (ang. micro-management) i detalicznego przeregulowania (ang. over-regulation) pozwoli im pełniej korzystać z własnej podmiotowości i skuteczniej sterować własnym rozwojem (Aghion i in. 2010). Niemniej słabnąca kontrola państwa - które przestało być już uosobieniem interesu ogólnego - musiała zostać zastąpiona przez większą społeczną rozliczalność (ang. public accountability), wszak uczelnie europejskie są w dominujący sposób finansowane z pieniędzy publicznych (Huisman i Currie 2004). Dało to początek zjawisku określanemu mianem boardyzmu (Veiga et al., 2015), w wyniku którego nastąpiło odejście od kontroli procesu realizacji misji przez administrację państwową na rzecz ewaluacji efektów, co oznacza że w pewnym sensie uczelnie zaczęły funkcjonować 
jako aktorzy korporacyjni (Amaral i in. 2003), nie tylko definiując własne struktury, ale również aktywnie angażując się w relacje z podmiotami z otoczenia społeczno-gospodarczego (Krucken i Meyer 2006).

\section{Uczelnie w centrum społeczeństwa postindustrialnego}

Przemiany koncepcji nowoczesnego państwa narodowego miały istotny wpływ na rozwój społeczeństwa interesariuszy w szkolnictwie wyższym, jednak rosnąca rola zewnętrznych interesariuszy jest również wynikiem strukturalnych przemian w gospodarce, w wyniku których nastąpiło przesunięcie instytucji szkolnictwa wyższego z gospodarczych peryferii w kierunku centrum (Drucker 2011; Bell 2008; Stehr 1994). Umasowienie szkolnictwa wyższego spowodowało, że już w latach 70. XX wieku uczelnie przestały kształcić wyłącznie elitę na potrzeby administracji państwowej czy szerzej sektora publicznego. W konsekwencji obok instytucji państwa również przedstawiciele sektora prywatnego zaczęli rościć sobie prawo artykułowania oczekiwań wobec funkcjonowania uczelni i mieć wpływ na organizację procesu kształcenia studentów. Ponadto zaczął zwiększać się również popyt na badania naukowe, co wynikało ze zmiany statusu wiedzy akademickiej i wzrostu znaczenia wiedzy teoretycznej w tworzącym się społeczeństwie postindustrialnym (Drucker 2011; Bell 2008). Wiedza stała się źródłem przewagi konkurencyjnej w gospodarce oraz podstawą tworzenia polityk publicznych, a konsekwencją nowej roli wiedzy teoretycznej miał być wzrost zatrudnienia w sektorze opartym na wiedzy, a także zwiększenie dochodów płynących z sektora przetwarzającego informację jako udziału w produkcie narodowym brutto (Drucker 2011: 198). Daniel Bell (2008) dostrzegal, że w społeczeństwie postindustrialnym zasobami o znaczeniu strategicznym stały się wiedza i umiejętności, które zastępują (wypierają) kapitał oraz pracę.

Stawiało to szkolnictwo wyższe nie tylko w zupełnie nowej roli, ale nakładało też na nie całkowicie nowe zadania, czyniąc je nie tylko współodpowiedzialnym za rozwój gospodarczy, ale wręcz lokując w jego centrum (Bell 1980: 500-501). Koncepcja ta została rozwinięta przez Lowe (1982) oraz Jorge Sábato i Michaela Mackenzie'go (1982), a następnie przez Henry'ego Etzkowitza (1993) oraz Etzkowitza i Loeta Leydesdorffa (1995) w formie modelu The Triple Helix opartego na trzech filarach uniwersytet-przemysł-rząd. Implikuje to zdecydowanie bardziej instrumentalne (Olsen i Maassen 2007) podejście do szkolnictwa wyższego, które według Marka Kwieka wiąże się „z przeformułowaniem, jeśli nie wręcz zakwestionowaniem, tradycyjnych, nowoczesnych ról społecznych uniwersytetu (zwłaszcza ról wynikających z wersji rozpowszechnionych na kontynencie europejskim, które zostały następnie spopularyzowane w różnych częściach świata - w tym niemieckiej wersji humbold- 
towskiej i francuskiej wersji napoleońskiej z początku XIX wieku)" (Kwiek 2010: 10). Patrycja Gumport (2000: 74) formułuje jeszcze dalej idące wnioski wskazujące na zmianę definicji szkolnictwa wyższego postrzeganej współcześnie jako instytucja odpowiedzialna za rozwój kapitału ludzkiego, który w ponowoczesnej gospodarce stanowi kluczowy zasób do budowania przewagi konkurencyjnej poszczególnych organizacji czy też całych gospodarek. Zmienia to zasadniczo instytucjonalną pespektywę patrzenia na uniwersytety, gdzie te ostatnie niejako same (środowiskowo) definiowały sobie cele na perspektywę instrumentalną, w której uczelnie stają się organizacjami działającymi dla realizacji celów określonych im przez zewnętrznych interesariuszy (Olsen 2007). Co więcej, wraz ,ze spadającym zaufaniem do instytucji (zwłaszcza publicznych) następuje redefinicja oczekiwań wobec publicznego szkolnictwa wyższego jako instytucji. Podczas gdy parsonowskie funkcje wzorów-utrwalonych i socjalizacyjnych znajdują się w odwrocie, to ekonomiczne funkcje mogą mieć dominujący charakter" (Gumport 2000: 74).

W wymiarze politycznym kluczowym dokumentem dla uniwersytetów europejskich, punktem zwrotnym w organizacji myślenia i wyznaczaniu im nowej roli jest przyjęta przez Unię Europejską Strategia Lizbońska (European Council 2000) oraz cały szereg późniejszych dokumentów wypracowanych przez Komisję Europejską (European Council 2005). W XXI wieku szkolnictwo wyższe stało się zbyt ważną częścią gospodarki, aby władze pozostawiły je wyłącznie w gestii uczonych, mimo że wielowiekowa tradycja instytucji akademickich w Europie gwarantowała im (nie było wówczas szkolnictwa wyższego jako systemu) pewną autonomię w kwestiach kształcenia, badań naukowych, a zwłaszcza polityki personalnej. Dla Kwieka nowa polityka wiąże się „,z przeformułowaniem, jeśli nie wręcz zakwestionowaniem, tradycyjnych, nowoczesnych ról społecznych uniwersytetu (zwłaszcza ról wynikających z wersji rozpowszechnionych na kontynencie europejskim, które zostały następnie spopularyzowane w różnych częściach świata - w tym niemieckiej wersji humboldtowskiej i francuskiej wersji napoleońskiej z początku XIX wieku) (Kwiek 2010: 20)”, co na poziomie politycznym zostało explicite verbis wyrażone w Strategii Lizbońskiej przypisującej uczelniom pomocniczą rolę w działaniach na rzecz rozwoju gospodarki opartej na wiedzy. Wprawdzie polityczne plany zakreślone w Lizbonie przez przywódców państw europejskich nigdy nie zostały zrealizowane, jednak Strategia Lizbońska pokazywała centralną, choć instrumentalną rolę uczelni oraz instytutów badawczych w budowaniu gospodarki opartej na wiedzy. Główne przesłanie Strategii Lizbońskiej - zwiększenie poziomu nakładów na badania naukowe do 3\% PKB często przejawiało się $\mathrm{w}$ dyskusjach nad kierunkiem zmian w polskim szkolnictwie wyższym, ale rzadko towarzyszył temu postulat instrumentalizacji uczelni i podporządkowania ich polityce rozwoju gospodarczego. 


\section{Ustrojowe konsekwencje przemian w szkolnictwie wyższym}

Odpowiedzią na te przeobrażenia była modernizacja rozwiązań ustrojowych instytucji akademickich. Miała ona przygotować uczelnie do funkcjonowania w zupełnie nowych warunkach, znacząco odmiennych od tych, które istniały w okresie formułowania koncepcji nowoczesnego uniwersytetu na początku XIX wieku czy też podczas fali demokratyzacji instytucji akademickich w latach 60. XX wieku. Zresztą w obu tych przypadkach ustrój uczelni reformowano pod silną polityczną presją otoczenia zewnętrznego, którego uczelnie nie były w stanie ignorować. Podobnie stało się z menedżerską falą reform ustrojowych (Amaral i in. 2003) - wraz z radami powierniczymi jako ich integralną częścią - które nabrały dynamiki w wyniku politycznych inicjatyw powstałych poza obszarem szkolnictwa wyższego (de Boer i in. 2010). W miejsce narzuconego przez państwo regulowanego porzą dku i bezpośredniego mikrosterowania uczelniami poprzez gęstą sieć biurokratyczne przepisów pojawiły się organizacje o szerokiej autonomii organizacyjnej, których ani struktura, ani sposób funkcjonowania nie są określone ustawowo (Enders i in. 2013). Państwo natomiast przyjęło logikę pośredniego zaangażowania poprzez zdalne sterowanie (ang. steering at a distance) (Kickert 1995), które pozwala władzy publicznej formułować oczekiwania wobec szkolnictwa wyższego, wyznaczać cele oraz dokonać ich regularnej ewaluacji. Osłabienie relacji między uczelnią a instytucją państwa wynikało również z kryzysu państwa opiekuńczego (Huber i Stephens 2001), które musiało sprostać wydatkom na ubezpieczenia społeczne, służbę zdrowia czy bezpieczeństwo. Jako że nakłady publiczne są zawsze grą o sumie zerowej, to zwiększenie wydatków na jedne cele zawsze odbywa się kosztem innych. Konsekwencją tego jest konkurowanie o publiczne finansowanie z innymi częściami sektora publicznego, które w politycznej walce często zyskują (zwłaszcza służba zdrowia i bezpieczeństwo) większą społeczną legitymizację aniżeli szkolnictwo wyższe (Kwiek 2003b: 98).

Nowy model ustroju uczelni miał usamodzielnić i przygotować je do funkcjonowania w warunkach quasi-rynkowych, które różnią się istotnie od regulowanego porządku, w którym państwo opiekuńcze zobowiązywało się bezwarunkowo i podmiotowo finansować publiczne uczelnie. Wspomniane wyżej przeobrażenia zarówno w instytucji państwa, jak również w strukturze gospodarki spowodowały konieczność redefinicji ustroju uczelni. Fala menadżerskich reform zmierzała w kierunku dostrojenia (używając modelu ukutego przez: de Boer, Enders i Schimank 2007) ustroju do nowych warunków funkcjonowania uczelni. W ich wyniku uczelnie ewoluują w kierunku sterowalnych od strony zarządczej kompletnych organizacji (ang. complete organizations) (Brunsson i Sahlin-Andersson 2000), w których wzrasta znaczenie aparatu zarządczego oraz administracyjnego uczelni kosztem społeczności akademickiej. Kompletne organizacje są przeciwieństwem loosely coupled, które 
zbudowane są „z różnych słabo powiązanych ze sobą elementów, z których każdy zachowuje własną tożsamość i odrębność w związku z tym ich powiązanie może być ograniczone, sporadyczne, nieistotne pod kontem wzajemnego oddziaływania, mało ważne oraz powolne w reagowania na zmiany" (Weick 1976: 3).

Istnieje wiele opracowań poświęconych reformom ustrojowym implementowanym w europejskim szkolnictwie wyższym (np. Kehm i Lanzemdorf 2006; Bleiklie i Kogan 2007; Gornitzka, Maassen i de Boer 2017), ale z punktu widzenia tego artykułu istotne są ustalenia zespołu kierowanego przez Antonia Amarala (Amaral, Tavares i Santos 2013). Badania te pokazują, że realizowane pod szyldem Nowego Zarządzania Publicznego (NZP) (Ferlie, Musselin i Andresani 2009) reformy charakteryzują się: (a) zwiększeniem autonomii organizacyjnej, (b) koncentracją władzy w uczelniach w pionie zarządczym oraz (c) włączeniem przedstawicieli zewnętrznych interesariuszy, których obecność w strukturze uczelni służyła „wprowadzeniu do instytucji szkolnictwa wyższego zarówno wrażliwości na potrzeby świata zewnętrznego, jak i praktyk zarządczych spoza świata akademickiego" (Magalhães i in. 2016: 2). Integralną częścią tych ustrojowych reform było wprowadzenie do ustroju instytucji akademickich nowego organu rad powierniczych (ang. supervisory boards), które tworzyły instytucjonalny pomost między uczelniami a szeroko rozumianym otoczeniem społeczno-gospodarczym. Ich utworzenie stanowi symboliczne otwarcie się uczelni na świat zewnętrzny, gdyż dotychczas europejskie uniwersytety były raczej hermetycznymi organizacjami skupionymi w pierwszej kolejności na zaspokajaniu potrzeb wewnętrznych interesariuszy, to jest kadry naukowej a zwłaszcza profesury oraz studentów, co było o tyle zrozumiałe, że to oni wybierali władze uczelni, zasiadali w senacie i to przed nimi te władze odpowiadały. Mimo, że niewątpliwą inspiracją i motorem napędowym reform ustrojów były idee NZP, to otwarcie się na zewnętrznych interesariuszy wynikało również z potrzeby większej odpowiedzialności uczelni oraz ich wrażliwości na potrzeby środowiska zewnętrznego. Rady powiernicze tworzyły jednak znacznie większe możliwości, gdyż wytyczały organizacyjną przestrzeń do włączania osób spoza wspólnoty akademickiej w proces zarządczy, a tym samym do wykorzystania ich kompetencji oraz doświadczenia w procesie kierowania uczelnią. Jednocześnie to właśnie otwarcie bram dla osób z zewnątrz, a zwłaszcza przypisanie im ustrojowych kompetencji budziło i nadal budzi największe środowiskowe obawy.

\section{Struktura i kompetencje rad powierniczych w Europie}

Warto podkreślić, że w poszczególnych krajach Europy Zachodniej idea rad powierniczych została w różny sposób zaadoptowana z uwzględnieniem lokalnej tradycji akademickiej oraz ustrojowej specyfiki instytucji akademickich. Stąd wynika stosunkowo 
duże zróżnicowanie ich kompozycji, zakresu posiadanej władzy oraz odpowiedzialności, sposobu mianowania/odwoływania ich członków, rozliczania rady powierniczej, a nade wszystko ich składu w tym zwłaszcza udziału reprezentantów zewnętrznych interesariuszy. Wprowadzenie rad powierniczych, a zwłaszcza umożliwienie osobom spoza uczelni na współdecydowanie o kierunku ich rozwoju nie spowodowało jednak rewolucyjnych zmian, choć społeczności akademickie przyjmowały je z pewnym (w niektórych krajach nawet sporym) sceptycyzmem. Studia nad radami powierniczymi (de Boer i in. 2010; Dragsic i in. 2011) pokazują, że w europejskich uczelniach rady mają wpływ na decyzje dotyczące strategii, rozwoju oraz konstrukcji budżetu, a także są zaangażowane w proces selekcji, wyboru kandydatów na stanowisko rektora (prezydenta) uniwersytetu lub także władz uniwersyteckich. Jednocześnie te same badania wskazują obszary, nad którymi rady powiernicze albo w ogóle nie mają formalnej władzy, albo jest ona mocno ograniczona: (a) polityki personalnej w tym również stanowisk profesorskich; (b) spraw rekrutacji i generalnie spraw studenckich oraz (c) aspektów dydaktycznych.

W zasadzie można powiedzieć, że zakres ich władzy objął całość organizacyjnej strony uczelni, dystrybucję i sposób wykorzystania finansowych zasobów oraz strategiczne zarządzanie uczelnią. Jest to obszar, w którym osoby spoza wspólny akademickiej mający doświadczenie w sferze zarządzania, ale bez balastu wewnętrznych interesów mogą wesprzeć zarządzanie uczelniami (Larson 2006), pozostawiając organizację procesu dydaktycznego i badań naukowych w gestii wspólnoty akademickiej.

\section{Role członków rad powierniczych}

Utworzenie rad powierniczych w szkołach wyższych jest często traktowane jako jeden spójny trend w szkolnictwie wyższym, który przy bliższej analizie skrywa bardzo różne treści. Zasadniczo można jednak wyodrębnić trzy typy rad powierniczych: (a) składające się wyłącznie z osób spoza wspólnoty akademickiej; (b) mieszane, ale składające się w większości z członków spoza wspólnoty akademickiej; (c) mieszane, składające się w mniejszości z członków spoza wspólnoty akademickiej. Pokazuje to, że ważnym, jeśli nie kluczowym elementem tworzenia rad powierniczych jest włączenie przedstawicieli zewnętrznych interesariuszy w struktury uczelni. Funkcjonowanie rad powierniczych w poszczególnych krajach różni się w zależności od realizowanych przez nie funkcji, trybu nominowania członków rad powierniczych, a także sposobu odgrywania swoich ról przez osoby zasiadające w radach. Warto podkreślić znaczenie czynnika ludzkiego, szczególnie w początkowym okresie, gdyż to powołane do rad osoby nadają nowo utworzonym strukturom funkcjonalny sens, poprzez swoje bieżące funkcjonowanie wytyczają ich praktyczny kształt, zwłaszcza 
wpisując je w silnie uksztaltowany i głęboko zakorzeniony w akademickiej tradycji instytucjonalny krajobraz ustroju uczelni.

Petr Kretek (Kretek i in. 2013) dokonał analizy form członkostwa w rad powierniczych w uczelniach. Wraz z zespołem analizował wyłącznie to, czego w rzeczywistości wymaga się od osób zasiadających w radach, jaka jest ich rola na podstawie sposobu ich powoływania i profilu osób zasiadających w radach.

Pierwszy z wyodrębnionych modeli można określić mianem rady reprezentującej interesy państwa (the state’s agents/supervisors), które najlepiej uosabia nadzorczą funkcję państwa, ale i pośrednią formę oddziaływania na uczelnie. W tym modelu decyzje rady są wyrazem oczekiwań rządu/ministerstwa odnośnie sposobu funkcjonowania uczelni, zwłaszcza kwestii budżetowych uczelni oraz strategicznych. Taka formuła funkcjonowania rady uczelni jest możliwa, jeśli w jej skład wchodzą przedstawiciele władzy tak jak w spółkach skarbu państwa bądź też osoby bezpośrednio przez nie powoływane/odwoływane. Sposób nominowania nie przesądza jednak o modelu funkcjonowania rady, gdyż w Holandii członkowie rad mianowani są przez władzę centralną, ale wywodzą się z grona szanowanych mieszkańców regionu i de facto bardziej są reprezentantami uczelni na poziomie centralnym aniżeli przedłużeniem ramieniem władzy wykonawczej w uczelniach (de Boer i File 2011).

Drugim wyodrębnionym typem jest model rady interesariuszy (societal/ private stakeholders), który wprost wpisuje się w ideę społeczeństwa interesariuszy. Członkami rady uczelni są bowiem przedstawiciele zewnętrznych interesariuszy i to ich interesy oni reprezentują, zresztą te ostatnie niekiedy kolidują ze sobą. Punktem wyjścia do formowania takiego modelu rady jest - omawiane tu wcześniej - przeświadczenie, że współczesna uczelnia jest częścią większego ekosystemu i nie powinna tego ignorować. Zresztą niezależnie od modelu rady jej obowiązkiem jest komunikowanie władzom uczelni oczekiwań i potrzeb płynących ze środowiska zewnętrznego. Istotną konsekwencją tego jest kompozycja rady uczelni, która w zamierzeniu ma odzwierciedlać różnorodność środowiska zewnętrznego. Dlatego w jej skład mogą wchodzić zarówno przedstawiciele sektora przedsiębiorstw, pracodawców, ale również lokalnych władz czy sektora pozarządowego. W gruncie rzeczy dużo zależy tu od specyfiki regionu, w którym ulokowane są uczelnie, ale i profilu samej uczelni. Rodzi to potencjalne problemy związane z konfliktem interesów, gdyż naturalnymi kandydatami do zasiadania w radach uczelni są osoby reprezentujące podmioty najbliżej z nią współpracujące. Wówczas rodzi się pytanie, czyj interes będzie miał dla nich pierwszeństwo i czy będą oni potrafili lączyć różne lojalności.

Kolejny wyodrębniony przez Kretka i współpracowników model funkcjonowania członków rad powierniczych wyróżnia rolę partnerów czy doradców (stewards/ partner) władz uczelni. W tym układzie członkowie rad uczelni przede wszystkim 
służą i wspierają władze uczelni jako eksperci, zwłaszcza przy podejmowaniu strategicznych decyzji organizacyjno-budżetowych. Ich obecność ma również poszerzyć perspektywę patrzenia na uczelnię i wyjść poza - związane z demokratycznym modelem ustroju - szukanie wewnętrznej równowagi między wydziałami (tzw. who gets what). Ich wartość dodana związana jest z przełamaniem głęboko zakorzenionej logiki myślenia o uczelni jako organizacji hermetycznej, tak mocno skupionej na sobie, że wręcz oderwanej od otaczającej jej rzeczywistości. Naturalnie sposób funkcjonowania członków rady wymaga mianowania/wyboru osób o wysokich kompetencjach i unikalnej wiedzy, którzy są w stanie wesprzeć proces zarządczy. Powinni stanowić oni merytoryczne wsparcie dla władz uczelni w obszarach krytycznych dla jej rozwoju, a jednocześnie tych, w których jej władze mają największe deficyty kompetencyjne. Taka rola członków rad uczelni implikuje bardziej partnerskie niż nadzorcze relacje pomiędzy radą a rektorem (czy szerzej zarządem uczelni). Gdy członkowie rady (lub rada jako całość) zostają włączeni w proces decyzyjny jako doradcy i partnerzy - jednocześnie słabnie ich funkcja nadzorcza.

Ostatnią formułą członkostwa w radach powierniczych jest model dekoracyjno-legitymizujący (rubber stamps/legitimizers), który zakłada absolutnie minimalną, wręcz fasadową rolę członków. Ich znaczenie staje się istotne dla władz uczelni ze względu na piastowane przez nie funkcje poza szkolnictwem wyższym, cieszą się wysoką pozycją społeczną i mają dobrze rozwinięte sieci kontaktów, z których również uczelnia może korzystać. Milcząco zakłada się, że członkowie rady ze względu na liczne własne zobowiązania nie będą mieli czasu na bieżące zajmowanie się sprawami uczelni, a ich obecność będzie sprowadzała się do legitymizacji poczynań władz uczelni, aczkolwiek w razie potrzeby również do wspierania uczelni poprzez rozliczną sieć kontaktów. Taki model funkcjonuje w wielu rosyjskich uczelniach.

Analizowane modele członkostwa w radach uczelni zależą przede wszystkim od: (a) sposobu mianowania jej członków, ściśle związanego z tym problemu (b) odpowiedzialności, a także (c) profilu i zaangażowania samych członków rady. Istnieją kluczowe czynniki, które w dużej mierze determinują sposób funkcjonowania rad uczelni, a to oznacza, że w ramach jednej ustawy modele rad poszczególnych uczelni mogą się różnić. Ustrój uczelni nie jest bowiem wyłącznie strukturą prawno-instytucjonalną, ale tak jak wskazuje definicja Eurydice (2008), jest zarówno formalnym, jak i nieformalnym sposobem sprawowania władzy. Inaczej mówiąc, analiza rad powierniczych musi uwzględniać nie tylko ich formalne ulokowanie, sposób powoływania/odwoływania czy zakres kompetencji, ale również to w jaki sposób tym strukturom nadawany jest sens przez różnych aktorów w procesie wzajemnych interakcji. 


\section{Funkcjonowanie rad powierniczych z perspektywy władz uczelni}

Wprowadzenie rad powierniczych lub też przypisanie im istotnej roli w procesie zarządzania uczelnią nastąpiło stosunkowo niedawno w większości krajów europejskich. Z tego powodu trudno jest na tym etapie dokonać oceny tego, jak zostały one wpisywane i przyjęte przez konserwatywną społeczność akademicką. W tym kontekście warto przywołać badania realizowane przez zespół kierowany przez Antonia Magalhãesa (Magalhães i in. 2016), który sprawdzil, w jaki sposób rady uczelni postrzegane są przez rektorów, a więc osoby (organy), z którymi najbliżej współpracują i z którymi najczęściej wchodzą w interakcje. Jego ustalenia zdają się potwierdzać hipotezę, że uniwersytety jako instytucje o utrwalonych wzorach funkcjonowania wpisanych i głęboko zakorzenionych w tradycji akademickiej powoli „oswajają” rady powiernicze i szukają sposobów wykorzystania ich potencjału. Na wstępie warto zaznaczyć, że otwarcie uczelni na zewnętrznych interesariuszy i dopuszczenie ich do współzarządzania uczelnią nie spowodowało rewolucji w funkcjonowaniu uczelni ani też ich bojkotu. Nie znaczy to, że proces implementacji upłynął bez politycznych perturbacji. Przeciwnie, fala reform menadżerskich w wielu krajach wywołała spore niezadowolenie w środowisku akademickim. Spory o nowy model ustroju, w tym zwłaszcza o rady uczelni, skończył się długą batalią sądowa w Austrii (Pechar 2005) oraz Finlandii (Ahola i Hoffman 2012). Jak pokazują jednak badania de Boera i Goedegebuure (2006: 238), katastroficzne wizje menadżerskiego zawłaszczania uczelni nie znajdują potwierdzenia. Społeczność akademicka ani nie czuje się wykluczona z procesu zarządzania, ani nie jest też przesadnie nieusatysfakcjonowana z procesu profesjonalizacji zarządzania uczelnią (zob. np. de Boer i in. 2010). Dzieje się tak po części dlatego, że mimo często katastroficznej retoryki nie nastąpiła rewolucja w bieżącym funkcjonowaniu uczelni, a dotychczasowe badania pozwalają na ostrożne formułowanie konkluzji, że tam gdzie wprowadzono rady powiernicze, funkcjonują one zasadniczo w sposób bezkolizyjny z innymi organami ustroju uczelni. Wskazują na to również wyniki badania przeprowadzonego wśród rektorów europejskich uczelni (Magalhães i in. 2016) wskazujące, że najchętniej widzieliby oni członków rad powierniczych jako ważnych sojuszników, ale takich którzy utrzymują zdrowy dystans. Najlepiej gdyby jej skład stanowili non-interfering friends, którzy nie będą angażowali się w bieżące funkcjonowanie uczelni, pozostawiając je pracownikom akademickim (Magalhães i in. 2016: 13).

\section{Polska debata nad radami uczelni}

Pomysł wprowadzenia rad powierniczych, określanych formalnie „radami uczelni”, pojawił się po raz pierwszy w debacie publicznej w okresie rządów Barbary Kudryckiej 
(2007-2008), ale Ministerstwo Nauki i Szkolnictwa Wyższego szybko się z niego wycofało ze względu na miażdżącą krytykę środowiska akademickiego. W gruncie rzeczy jednak w polskich warunkach nie odbyła się poważna debata dotycząca modelu ustroju uczelni, a okazjonalna wymiana poglądów ma charakter głównie publicystyczny. Ta ostatnia zdominowana jest przez emocjonalny charakter wypowiedzi, które wyłącznie odzwierciedlają środowiskową wagę tocznych sporów.

Idea wprowadzenia rad powierniczych napotkała przede wszystkim krytykę płynącą ze strony akademii, która dość jednoznacznie okazuje sprzeciw wobec wszelkich form włączenia do uczelni osób spoza wspólnoty akademickiej. Są one przede wszystkim traktowane jako polityczne inicjatywy zmierzające do ograniczenia autonomii uniwersytetów i stąd generalnie negowane przez środowisko akademickie. Daleko posuniętemu sceptycyzmowi społeczności akademickiej towarzyszą obawy artykułowane na trzech płaszczyznach: ideowej, prakseologicznej oraz władzy.

Najsilniejsza krytyka następuje na płaszczyźnie ideowej, w której rady powiernicze utożsamiane są z radykalnym odejściem od uczelni odwołującej się do idei „wspólnoty uczonych”. Silę ich tożsamościowego znaczenia pokazują badania prowadzone przez Kwieka (2014), stąd też wszelkie próby reform, jako uderzenie w autonomię instytucji akademickich, napotykają opór środowiska. Co ciekawe, to jednowymiarowe rozumienie autonomii, które ogranicza ją wyłącznie do politycznego aspektu, zostało w dużej mierze ukształtowane historycznie w okresie obrony uczelni przed ingerencją władz komunistycznych. To ważne doświadczenie stało się niewątpliwie istotnym powodem pojawienia się na początku lat $90 . \mathrm{XX}$ wieku niemal utopijnych postulatów zamknięcia uniwersytetów na jakiekolwiek oddziaływanie świata zewnętrznego. Dla przykładu Ustawa Prawo o szkolnictwie wyższym z 1990 roku, która mimo tego, że dawała uczelniom szeroką autonomię w każdym wymiarze, to i tak spotkała się ze środowiskową krytyką, o czym pisze jeden z jej twórców, Tadeusz Popłonkowski. „Krytyka ustawy następuje przede wszystkim z pozycji tradycyjnej, wręcz idealistycznie pojmowanej autonomii uczelni jako systemu zamkniętego na wpływy otoczenia" (Popłonkowski 1996: 125). Cechy tej autonomii widzi się w pozbawieniu możliwości oddziaływania wszelkich podmiotów pozauczelnianych, $\mathrm{w}$ tym organów państwa i ciał pozauczelnianych, niezależnie od ich składu. Wprawdzie postulaty bezwarunkowej i całkowitej autonomii nigdy nie zostały spełnione, ale przekonanie o tym, że funkcjonowanie uczelni winno pozostać wyłącznie wewnętrzną sprawą społeczności akademickiej, pozostaje ważnym elementem środowiskowej tożsamości. Jednocześnie pogląd ten koliduje z ideą wprowadzenia rad powierniczych, które otwierają uczelnie na świat zewnętrzny, włączając do jej funkcjonowania (i zarządzania) przedstawicieli zewnętrznych interesariuszy. Wielu przedstawicieli środowiska akademickiego właśnie na płaszczyźnie ideowej fundamentalnie odrzuca koncepcje rad uczelni jako ograniczającej samorządność akademicką i autonomię 
wspólnoty uniwersyteckiej. Świadczyć może o tym list 145 profesorów skierowany do wicepremiera i ministra nauki i szkolnictwa wyższego Jarosława Gowina w sprawie wprowadzanych przez niego reform. Sygnatariusze listu formułują dziesięć postulatów, który otwiera ten odnośnie rad uczelni: „,...] po pierwsze, należy zaniechać planu tworzenia rad uczelni złożonych z osób wprowadzonych z zewnątrz w ponad połowie ich członków²". Ich sposób myślenia wpisuje się ideologicznie w skrajnie lewicowy nurt krytyki rad powierniczych upatrujących w nich neoliberalną trend zmierzający do urynkowienia uniwersytetów. Poddając krytyce pomyły trzech zespołów przygotowujących założenia do Ustawy 2.o (z których każdy zakładał obecność rad uczelni), wskazują oni, że: „wedle autorów i autorek omawianych projektów cudownym środkiem na wyleczenie uczelni z nadmiaru demokracji jest przyznanie decydującego głosu interesariuszom zewnętrznym, wywodzącym się przede wszystkim ze świata biznesu [...] pokazują skrywane pod płaszczykiem frazesów o «autonomii» i «niezależności» neoliberalne dążenie do podporządkowania działania uczelni logice rynkowej konkurencji”3. Idea wprowadzenia rad powierniczych do uczelni budzi zarówno ogromne obawy środowiskowe, jak i sprzeciw wielu środowisk politycznych, które upatrują w niej zagrożenie dla tradycyjnie postrzeganego uniwersytetu.

Druga płaszczyzna, na której odbywa się krytyka koncepcji rad powierniczych, ma charakter prakseologiczny. Przeciwnicy rad powierniczych - nie kwestionując zasadniczo samej idei - wskazują na przeszkody implementacyjne w polskich warunkach. Przede wszystkim jest to brak tradycji funkcjonowania takich organów w polskim szkolnictwie wyższym, który powoduje, że nie ma rezerwuaru lokalnych dobrych praktyk organizacyjnych, z których można korzystać przy ich tworzeniu. Badania nad organizacjami (DiMaggio i Powell 1983) pokazują, że przy braku modeli gotowych do implementacji organizacje mają tendencję do naśladownictwa i korzystają z zakorzenionych $\mathrm{w}$ danej kulturze wzorów organizacyjnych. W polskim kontekście nie ma rezerwuaru dobrych praktyk funkcjonowania takich organów, natomiast istnieje ogromne niebezpieczeństwo przeniesienia - jedynych dostępnych wzorów działalności rad nadzorczych instytucji publicznych, które są w Polsce skrajnie upolitycznione $e^{4}$ służą partiom do zawłaszczania instytucji publicznych. Naturalnie można oczekiwać, że nastąpi odwołanie do sprawdzonych i relatywnie dobrze funkcjonujących modeli rad powierniczych w innych krajach takich jak Austria, Finlandia, Niemczy czy Holandia, ale taki transfer jest mało prawdopodobny w tak silnie hermetycznym systemie szkolnictwa wyższego jak polski. Ponadto transfer

${ }^{2}$ Treść listu 145 profesorów można przeczytać na: http://www.gazetaprawna.pl/artykuly/1107125,list-145-naukowcow-reforma-gowina-zawiera-grozne-rozwiazania.html [10.04.2018].

3 Zob. http://krytykapolityczna.pl/nauka/neoliberalny-zamach-na-nauke/ [10.04.2018].

4 Trzeba zaznaczyć, że również w krajach o wyższej kulturze politycznej zdarzają się incydenty wskazujące, że patologiczne zjawiska w radach zdarzają się wszędzie, ale narażone są na to zwłaszcza małe kraje jak choćby Austria (Nature 2008). 
idei i dobrych praktyk możliwy jest, gdy osoby zasiadające w radach powierniczych posiadają doświadczenie pracy w radach uczelni wspomnianych krajów i mogłyby przenieść je na inny grunt. Jest to jednak mało prawdopodobne, natomiast nie da się wykluczyć scenariusza, w którym do rad uczelni wejdą osoby korzystające wylącznie z rezerwuaru istniejących lokalnie rozwiązań instytucjonalno-kulturowych, do których mają dostęp.

Trzecia płaszczyzna krytyki odnosi się - jakkolwiek niebezpośrednio - do kwestii władzy w uczelniach, których organizacja i funkcjonowanie stanowiły wyłącznie domenę społeczności akademickiej - wewnętrznych interesariuszy. Niewątpliwie wprowadzenie rad powierniczych zmieni wewnętrzny układ władzy, ograniczając zakres wpływu społeczności akademickiej (zwłaszcza profesury) na rzecz osób spoza uczelni. W wielu krajach opór „akademickiej oligarchii” był najbardziej widoczny, czego sztandarowym przykładem są Włochy (Reale i Potì 2009) i Austria (Pechar 2012). Wprowadzenie koncepcji shared governance (Wilson i Chapman 2013), do której odwołuje się Michaella Shattock (2002) oznacza, że społeczność akademicka musi oddać część posiadanej przez siebie władzy na rzecz zewnętrznych interesariuszy. Ci ostatni powinni skupiać się głównie na aspektach strategicznych oraz organizacyjno-zarządczych, ale nie ingerować w sprawy badań oraz kształcenia, pozostawiając te ostatnie w kompetencji społeczności akademickiej. Idea powołania rad powierniczych tworzy zrozumiały opór, zwłaszcza w kontekście wyboru władz uczelni. Analizy de Boera (2018) pokazują, że jedną z podstawowych kompetencji rad powierniczych jest uczestnictwo w wyborze władz uczelni, a więc symbolicznie jednego z najważniejszych aspektów autonomii (i władzy) w polskim szkolnictwie wyższym. Ich wprowadzenie jest też symbolicznym odejściem od koncepcji uczelni jako wspólnoty uczonych, które w polskich warunkach (głównie ze względu na biurokratyczne regulacje sektora publicznego) jest już bardziej elementem mitologii akademickiej aniżeli częścią rzeczywistości. Włączenie rad powierniczych do ustroju instytucji akademickich odbiera społeczności wyłączne prawo wyboru jej władz, a tym samym odbiera znaczącą część posiadanej przez niej władzy, która w pozostałych aspektach (np. finansowym) została jej już dawno odebrana przez aparat biurokratyczny.

Środowisko akademickie bardzo sceptycznie odnosi się do koncepcji wprowadzenia rad powierniczych, ale jednocześnie warto zauważyć, że w toczących się dyskusjach w zasadzie brakuje osób spoza lokalnego polskiego środowiska akademickiego. Najlepiej świadczy o tym niemal całkowicie przemilczany (w zasadzie ostentacyjnie zignorowany) w dyskusji środowiskowej raport sporządzony przez międzynarodowych ekspertów pod auspicjami Komisji Europejskiej i zaprezentowany w czasie Narodowego Kongresu Nauki, w którym dość jednoznacznie zostało pokazane stanowisko dotyczące rad powierniczych, „panel zgadza się, że typ przed- 
stawicieli zewnętrznych interesariuszy powinien odzwierciedlać misje i profil uczelni, ale podkreślił, że wszystkie typy uczelni powinny być wyposażone w rady" (European Commission 2017: 65). Pokazuje to, że polskie szkolnictwo wyższe nawet w aspekcie dyskursywnym pozostaje całkowicie zamknięte na udział osób spoza środowiska akademickiego, ale w efekcie tego wyraźnie pozostaje osamotnione w swych staraniach o lepsze publiczne i prywatne finansowanie.

Interesującym wydaje się fakt, że nie tylko raport ekspertów Policy Support Group (European Commission 2017), ale także wszystkie trzy zespoły eksperckie przygotowujące projekt reform do Ustawy 2.0 wspierały powołanie organów stanowiących most między uczelnią a światem zewnętrznym. Mimo to w polskim środowisku dominuje sceptycyzm i na próżno szukać głosów wspierających idee rad powierniczych, co wskazuje również na napięcia między eksperckim wymiarem dyskursu, który jest bardzo ubogi, a głosem środowiskowym, który zdecydowanie dominuje w dyskusjach nad radami uczelni.

\section{Podsumowanie}

Rady powiernicze w uczelniach symbolizują kierunek przemian społecznych oraz gospodarczych, w efekcie których następuje redefinicja roli szkolnictwa wyższego, a co za tym idzie również ustroju szkół wyższych. Mimo to rady napotykają na naturalny opór środowiska akademickiego, a nawet bunt wobec nowych rozwiązań ustrojowych nieprzystających często do głęboko zakorzenionych i niemal uświęconych w tradycji akademickiej modeli ustrojowych. Niechęć do wprowadzania rad powierniczych wynika również z tego, że ich inicjatorem jest władza polityczna, a ich orędownikami są dużej mierze politycy, a czasami również przedsiębiorcy, w każdym razie głównie osoby spoza środowiska akademickiego. W krajach Europy Zachodniej polityczne inicjatywy zmierzające do zreformowania szkolnictwa wyższego były wprowadzane już od zakończenia II wojny światowej, a w Polsce przez dekady były kojarzone wyłącznie z próbą politycznej ingerencji władz komunistycznych w wolność akademicką, stąd po 1989 roku rząd wycofał się z tego obszaru, ograniczając się do biernego administrowania. Dopiero Reformy Kudryckiej (2008-2010) były pierwszą polityczną inicjatywą zmierzającym do wyraźnej zmiany status quo, który zresztą napotkał bardzo silny opór środowiska akademickiego przez niemal dwadzieścia lat przyzwyczajonego do modelu polityki braku polityki naukowej (ang. policy-of-nopolicy) (Antonowicz 2015). Reformy zaproponowane w Ustawie 2.0 kontynuują rozpoczęte wcześniej polityczne, kulturowe oraz instytucjonalne przemiany, a wprowadzenie rad uczelni byłoby ich naturalną konsekwencją. Opór środowiska akademickiego jest jednak poniekąd zrozumiały. Pod względem ustrojowym uczelnie to organizacje oparte na utrwalonych i silnie zsocjalizowanych wzorach funkcjono- 
wania i przypisanych im znaczeniach, których obecność jest legitymizowana przez tradycję akademicką (Maassen 2017). W tym kontekście rady traktowane są jako ciała obce, a przez niektórych nawet wrogie w polskim szkolnictwie wyższym, niepasujące do regulowanego porządku, do którego aktorzy w obszarze szkolnictwa się przyzwyczaili, podobnie jak do tego, że państwo ten porządek odgórnie narzuca. Wydaje się jednak, że wprowadzenie rad powierniczych do polskich uczelni jest wyłącznie kwestią czasu, choć ich kształt, sposób powołania, zakres kompetencji oraz formy rozliczalności będą zapewne polem ścierania się konkurujących modeli, a kluczową rolę odegra pierwsza kadencja nowych ciał, bowiem to ona ukształtuje sposoby ich funkcjonowania, w tym zwłaszcza relacje z pozostałymi aktorami zarówno wewnątrz, jak i na zewnątrz.

\section{Literatura}

Aarrevaara, T. (2012). Oh Happy Days!: University Reforms in Finland. W I. Dobson i F. Maruyama (red.), Cycles of University Reform: Japan and Finland Compared (79-92). Tokyo: Center for National University Finance and Management.

Aghion, P., Dewatripont, M., Hoxby, C., Mas-Colell, A. i Sapir, A. (2010). The governance and performance of universities: evidence from Europe and the US. Economic Policy. 25(61): 7-59.

Ahola, S. i Hoffman, D.M. (2012). Higher education research in Finland: emerging structures and contemporary issues. Jyväskylä: University of Jyväskylä.

Amaral, A. i Magalhães, A. (2001). On markets, autonomy and regulation the Janus Head revisited. Higher Education Policy. 14(1): 7-20.

Amaral, A., Meek, V.L. i Larsen, I.M. (2003). The Higher Education Managerial Revolution? Dordrecht: Springer Netherlands.

Antonowicz, D. (2005). Uniwersytet przyszlości: Wyzwania i modele polityki. Warszawa: Instytut Spraw Publicznych.

Antonowicz, D. (2015). Między siła globlanych procesów a lokalną tradycją: Polskie szkolnictwo wyższe $w$ dobie przemian. Toruń: Wydawnictwo UMK.

Bell, D. (2008). The Coming Of Post-industrial Society. New York: Basic Books.

Bleiklie, I. (1998). Justifying the Evaluative State: New Public Management Ideals in Higher Education. European Journal of Education. 33(3): 299-316.

Bleiklie, I. i Kogan, M. (2007). Organization and Governance of Universities. Higher Education Policy. 20(4): 477-493.

Boer, H. de, Enders, J. i Schimank, U. (2007). On the Way towards New Public Management? The Governance of University Systems in England, the Netherlands, Austria, and Germany. W: D. Jansen (red.), New Forms of Governance in Research Organizations (137152). Dordrecht: Springer Netherlands. 
Boer, H.F. de, Jongbloed, B.W.A., Enders, J. i File, J.M. (2010). Progress in higher education reform across Europe, Funding reform, Volume 1: Executive Summary and main report (CHEPS): Enschede. https://research.utwente.nl/en/publications/progress-in-highereducation-reform-across-europe-funding-reform--3 [10.04.2018].

Boer, H. de, Maasen, P. i Weert, E. de. (1999). The troublesome Dutch university and its Route 66 towards a new governance structure. Higher Education Policy. 12(4): $329-342$.

Boer, H. D., Denters, B. i Goedegebuure, L. (1998). On boards and councils; shaky balances considered The governance of Dutch universities. Higher Education Policy. 11(2-3): 153-164.

Brunsson, N. i Sahlin-Andersson, K. (2000). Constructing Organizations: The Example of Public Sector Reform. Organization Studies. 21(4): 721-746.

De Boer, H.F., Enders, J. i Leisyte, L. (2007). Public sector reform in Dutch higher education: The organizational transformation of the university. Public Administration. 85(1): 27-46.

De Boer, H.F., \& File, J. (2011). Old Wine in New Skins: The long Evolution of Supervisory Boards in Duthc Higher Education. W: J. Enders, H.F. De Boer i D.F. Westerheijden (red.), Reform of Higher Education in Europe (159-173). Rotterdam: SensePublishers.

de Boer, H., Huisman, J. i Meister-Scheytt, C. (2010). Supervision in 'modern' university governance: boards under scrutiny. Studies in Higher Education. 35(3): 317-333.

DiMaggio, P. i Powell, W. (1983). The Iron Cage Revisited: Institutionalised Isomorphism and Collective Rationality in Organizational Fields. American Journal of Sociology. 48(2): 147-160.

Drucker, P. (2011). The Age of Discontinuity: Guidelines to Our Changing Society. New Brunswick, N.J.: Transaction Publishers.

Enders, J., de Boer, H. i Weyer, E. (2013). Regulatory autonomy and performance: the reform of higher education re-visited. Higher Education. 65(1): 5-23.

European Commission. (2017). Peer Review of Polish Higher Education and Science System - RIO - H2O2O PSF - European Commission. Brussels: European Commission.

European Council. (2000). Lisbon European Council 23 and 24 March 2000 Presidency Conclusions. EC.

European Council. (2005). European Council Brussels 22 and 23 March 2005 Presidency Conclusions. EC.

Gornitzka, Å., Maassen, P. i de Boer, H. (2017). Change in university governance structures in continental Europe. Higher Education Quarterly. 71(3): 274-289.

Gumport, P. (2000). Academic restructuring: Organizational change and institutional imperatives. Higher Education. 39(1): 67-91.

Henkel, M. i Askling, B. (2006). Higher Education Institutions. W: M. Kogan, M. Henkel, P. M. Bauer i P.I. Bleiklie (red.), Transforming Higher Education (85-100). Dordrecht: Springer Netherlands. 
Huber, E. i Stephens, J.D. (2001). Development and Crisis of the Welfare State: Parties and Policies in Global Markets (1 ed.). Chicago: University Of Chicago Press.

Huisman, J. i Currie, J. (2004). Accountability in higher education: Bridge over troubled water? Higher Education. 48(4): 529-551.

Jabłecka, J. (2002). Menedżeryzm i państwo ewaluacyjne - zmiany w zarządzaniu uniwersytetami na przykładzie Wielkie Brytanii. W: M. Wójcicka (red.), Dywersyfikacja w szkolnictwie wyższym (63-81). Warszawa: Wydawnictwa UW.

Kehm, B. i Lanzemdorf, U. (red.). (2006). Reforming university governance: changing conditions for research in four European countries. Bonn: Lemmens.

Kersbergen, K.V. i Waarden, F.V. (2004). "Governance" as a bridge between disciplines: Cross-disciplinary inspiration regarding shifts in governance and problems of governability, accountability and legitimacy. European Journal of Political Research. 43(2): 143-171.

Klimke, M. i Scharloth, J. (2008). 1968 in Europe: A History of Protest and Activism, 19561977. London: Palgrave Macmillan.

Kretek, P. M., Dragšić, Ž. i Kehm, B. M. (2013). Transformation of university governance: on the role of university board members. Higher Education. 65(1): 39-58.

Kwiek, M. (2000). The nation-state, globalisation and the modern institution of the university. Theoria: A Journal of Social and Political Theory. 96: 74-98.

Kwiek, M. (2010). Transformacje uniwersytetu. Poznań: Wydawnictwo Naukowe UAM.

Kwiek, M. (2014). Uniwersytet jako „wspólnota badaczy”? Polska z europejskiej perspektywy porównawczej i ilościowej. Nauka i Szkolnictwa Wyższe. 2(40): 71-100.

Kwiek, M., Antonowicz, D., Brudlak, J., Hulicka, M., Jędrzejewski, T., Kowalski, R., Kulczycki, E., Szadkowski, K., Szot, A., Wolszczak-Derlacz, J. (2016). Projekt założeń do ustawy prawo o szkolnictwie wyższym. Poznań: Wydawnictwo Naukowe UAM.

Lowe, Roy. (1982). The Expansion of Higher Education in England. W: J. Konrad (red.), The transformation of higher learning 1860-1930: expansion, diversification, social opening and professionalization in England, Germany, Russia and the United States. Stuttgart: Klett-Cotta.

Luzzatto, G. i Moscati, R. (2005). University Reform in Italy: Fears, Expectations and Contradictions. W: Å. Gornitzka, M. Kogan i A. Amaral (red.), Reform and Change in Higher Education (153-168). Dordrecht: Springer Netherlands.

Magalhães, António, Veiga, A. i Amaral, A. (2016). The changing role of external stakeholders: from imaginary friends to effective actors or non-interfering friends. Studies in Higher Education, 1-17.

Magalhães, Antonio, Veiga, A., Amaral, A., Sousa, S. i Ribeiro, F. (2013). Governance of Governance in Higher Education: Practices and lessons drawn from the Portuguese case: Governance of governance in higher education. Higher Education Quarterly. 67(3): 295-311. Moodie, G.C. i Eustace, R. (1974). Power and authority in British universities. London: Allen \& Unwin.

Nature. (2008). Scandalous behaviour. Nature. 454(7207): 917-918. 
Neave, G. (2003). Perspektywa interesariuszy w ujęciu historycznym. Nauka i Szkolnictwo Wyższe. 21(1): 19-39.

Olsen, J.P. (2007). The Instituional Dynamics of European University. W: J.P. Olsen i P. Maasen (red.), University Dynamics and European Integration (25-55). Dordrecht: Springer Netherlands.

Olsen, J. P. i Maassen, P. (2007). European Debates on the Knowledge Institution: The Modernization of the University at the European Level. W: J.P. Olsen i P. Maasen (red.), University Dynamics and European Integration (3-25). Dordrecht: Springer Netherlands.

Pechar, H. (2005). Backlash or Modernisation? Two Reform Cycles in Austrian Higher Education. W: Å. Gornitzka, M. Kogan i A. Amaral (red.), Reform and Change in Higher Education (269-285). Berlin/Heidelberg: Springer-Verlag.

Pechar, H. (2012). The Decline of an Academic Oligarchy: The Bologna Process and 'Humboldt's Last Warriors'. W: A. Curaj, P. Scott, L. Vlasceanu i L. Wilson (red.), European Higher Education at the Crossroads (613-630). Dordrecht: Springer Netherlands.

Popłonkowski, T. (1996). Autonomia uczelni, instytucjonalne ograniczenia autonomii, kierunki zmian. W: M. Dąbrowa-Szefler i M. Pastwa (red.), Finansowanie i zarządzanie szkolnictwem wyższym Polska-Holandia (123-133). Warszawa: UW, CBPNiSW.

Reale, E. i Potì, B. (2009). Italy: Local Policy Legacy and Moving to an 'In Between' Configuration. W: C. Paradeise, E. Reale, I. Bleiklie i E. Ferlie (red.), University Governance (77-102). Dordrecht: Springer Netherlands.

Stehr, N. (1994). Knowledge societies. London-Thousand Oaks, CA: Sage.

Szwabowski, O. (2014). Uniwersytet - fabryka - maszyna: Uniwersytet $w$ perspektywie radykalnej. Warszawa: Instytut Wydawniczy Książka i Prasa.

Välimaa, J. (2007). Social Dynamics of Higher Education Reforms: The Case of Finland. W: Å. Gornitzka, M. Kogan i A. Amaral (red.), Reform and Change in Higher Education (245-269). Dordrecht: Springer Netherlands.

Veiga, A., Magalhães, A. i Amaral, A. (2015). From Collegial Governance to Boardism: Reconfiguring Governance in Higher Education. W: J. Huisman, H. De Boer, D.D. Dill i M. Souto-Otero (red.), The Palgrave International Handbook of Higher Education Policy and Governance (398-416). London: Palgrave Macmillan.

Weick, K. E. (1976). Educational Organizations as Loosely Coupled Systems. Administrative Science Quarterly. 21(1): 14.

Wójcicka, M. (red.). (2002). Dywersyfikacja w szkolnictwie wyższym: Uwarunkowania i perspektywy. Warszawa: UW, CBPNiSW.

Woźnicki, J., Brzeziński, J., Chałupka, M., Izdebski, H., Jędrzejewski, T., Krasowski, K., Kolasa, K., Leja, K., Malec, J. i Pacuska, M. (2015). Deregulacja w systemie szkolnictwa wyższego. Warszawa: Wydawnictwo SGGW. 


\section{Supervisory Boards in Higher Education}

ABSTRACT: The subject of this article is supervisory boards in European higher education. The analysis covers the process of shaping the idea of councils in various traditions of higher education, paying particular attention to the role they were assigned to building relations between universities and the external environment. This work is not only of historical nature, although a large part of it is devoted to the analysis of the discourse on the process of establishing and organizing councils in European universities. Its central element is the analysis of supervisory boards in universities in terms of their authority and responsibility, the manner of appointing/ dismissing their members, accounting for a trustee and, above all, their composition, in particular, the participation of representatives of external stakeholders. In the last part - referring to the experience of other countries - the issue of potential challenges that arise for Polish higher education in relation to the publicly discussed possibility of establishing supervisory boards at Polish universities is addressed.

KEYWORDS: higher education, governance of University, reforms, supervisory boards, stakeholder society

CYTOWANIE: Antonowicz, D. (2018). Rady powiernicze w szkolnictwie wyższym. Nauka i Szkolnictwo Wyższe. 1(51): 45-68. DOI: 10.14746/nisw.2018.1.2.

DOMINIK ANTONOWICZ - kierownik Zakładu Socjologii Nauki na Uniwersytecie Mikołaja Kopernika w Toruniu. Zajmuje się badaniem polityki publicznej w zakresie szkolnictwa wyższego, w tym zwłaszcza ewaluacją badań naukowych, a także ustrojem i zarządzeniem instytucjami akademickimi. Pracował w School of Public Policy, University of Birmingham (UK), Center of Higher Education Policy Studies (CHEPS) na University of Twente oraz Centro de Investigação de Políticas do Ensino Superior (CIPES) na University of Porto. Był także stypendystą rządu brytyjskiego (Chevening Scholar) oraz Fundacji na rzecz Nauki Polski („Start” oraz „Kolumb”). Od 2010 jest członkiem Komitetu Ewaluacji Jednostek Naukowych (KEJN). Autor książki Między siła globalnych procesów a lokalną tradycją: Polskie szkolnictwo wyższe $w$ dobie przemian (2015). 